\title{
International Financial Reporting Standards Implementation into the Russian Accounting System
}

\author{
Aletkin P.A. \\ Kazan Federal University, Institute of Management, Economics and Finance, Kazan, 420008, Russia
}

\section{Doi:10.5901/mjss.2014.v5n24p33}

\begin{abstract}
This study illustrates the process of implementing IFRS in Russia. The article deals with the description of the system of statutory regulation and its development through the process of International Financial Reporting Standards implementation. The problematic issues concerning the current state of the system of statutory regulation are systemized. The practical application of different accounting systems by Russian companies during the transition to International Financial Reporting Standards followed. The specifics of the financial statements performance are analyzed.
\end{abstract}

Keywords: implementation of International Financial Reporting Standards, accounting system, statutory regulation, voluntary adoption, financial results

\section{Introduction}

From the beginning of the transition to market economy the Russian accounting system undergoes substantial changes. As in many European countries financial reporting in Russia is regulated by state authorities. Taking into consideration scarce investment resources in the country the Government sets a goal of fast implementation of International Financial Reporting Standards into the Russian accounting system. The issues of introduction of international standards such as the necessity of statutory regulation reform, the development of high quality accounting standards by professional organizations are still a challenge so far.

The regulatory system of accounting where the Federal Law "On Accounting" is on the top of the regulatory hierarchy, is supplemented and completed by the number of other rules, issued by the Ministry of Finance. For the reason of low quality financial information disclosure the Government has to intervene to oblige the companies to publish financial reporting in compliance not only with Russian Accounting Standards but also with International Financial Reporting Standards (IFRS). Most of the biggest companies of the country are already performing financial reporting in compliance with IFRS on a voluntarily basis.

The analysis of International Financial Reporting Standards implementation into the Russian accounting system facilitates better understanding of what has to be done to improve this system.

\section{Background and Theoretical Development}

With the worldwide adoption of IFRS the number of studies considering the issues of international financial reporting standards implementation is growing exponentially. Reforms of corporate governance and accounting standards can increase the attractiveness of emerging markets by providing a more favourable environment for foreign investment, although typically these reforms are based on systems developed in advanced economies, and the reform process itself needs to be understood [1].

Many existing studies provide different aspects of IFRS implementation from EU perspective (Pope, P.F., McLeay, S.J. Rózsa, I.B.) or from a country-specific perspective as UK and Italy (Fox, A., Hannah, G., Helliar, C.,Veneziani, M.), Iraq (Hassan, E.A., Rankin, M., Lu, W.), Czech Republic (Paseková, M., Crhová, Z., Strouhal, J.,Rezanková, H.) Romania (Albu, N., Albu, C.N.). Some researchers state that is very important from the perspective of developing global accounting standards that the selected accounting regulation is applicable and plausible not only from technical perspectives, including recognition, measurement, presentation and disclosure assertions, but also from user perspectives to make standards friendly for everyone [9]. Others imply that it is still an open question to what extent positive capital-market effects around mandatory IFRS adoption are indeed attributable to arguably improved and globally harmonized accounting standards [3]. The consequences of IFRS implementation into the Russian accounting system in 
these studies are underexplored.

Alon, A indicates that in Russia, institutional change related to IFRS adoption was not revolutionary as IFRS did not replace Russian Accounting Standards (RAS) but both standards coexist [2].

Historically several attempts were made by the Russian accounting regulatory body - the Ministry of Finance aiming to reform the accounting system in the country. For the first time ever the Government decided to implement international accounting and statistics standards in 1992. From our point of view three periods of transition to International Financial Reporting Standards (IFRS) can be distinguished.

In the period covering 1992 - 2004 a number of several Acts by the Ministry of Finance was issued. According to the Program of Accounting System Reform endorsed by the Ministry of Finance in 1994 the transition to International Financial Reporting Standards had to be finished by 2000.

In addition Conceptual Framework for Accounting in market economy (1994), Program for the Reform of Accounting in Accordance with International Financial Reporting Standards (1998) and Conceptual Framework for Accounting and Reporting Development for Medium-term Perspective (2004) followed.

Indicated regulatory acts imported into the Russian accounting system conceptual framework for financial reporting based on international standards. Most of the accounting principles such as accrual-basis of accounting, accounting policies, materiality, substance over form appeared to be new for Russian practitioners.

In the period covering $2004-2010$ a number of Russian Accounting Standards underwent abrupt changes by the Ministry of Finance in order to bring them in line with International Financial Reporting Standards. In the critical 2004 a part of economic entities of the country was obliged to comply with IFRS. This happened as Central Bank ruled to prepare reporting in compliance with International Financial Reporting Standards for all banking institutions.

In the period covering 2010 - 2014 some Russian companies started to prepare financial reporting in compliance with IFRS on a voluntarily basis but in 2010 the scope of economic entities obliged to prepare financial reporting was broadened as the Federal law "On consolidated financial statements" has been endorsed. According to the Federal law only the consolidated statements had to be presented in compliance with International Financial Reporting Standards for such businesses as:

a) Banking institutions;

b) Insurance companies;

c) Listed companies.

According to new provision a listed company is exempted from preparing the consolidated statements in compliance with International Financial Reporting Standards if its publishes the consolidated financial statements with other internationally accepted accounting rules, for instance, US GAAP. These specified companies will have to comply with International Financial Reporting Standards no earlier than 2015. According to our previous research these companies in Russia were Mechel, Cherkizovo Group, Gazpromneft, Gals Development, Mobile TeleSystems, MGTS, NLMK, Rosneft, Lukoil, Slavneft-Megionneftegaz, Sistema JSFC, Tatneft, TNK-BP (before take over by Rosneft).

The Federal law "On consolidated financial statements" had facilitated the development of infrastructure for IFRS implementation into the Russian accounting system. To provide a legislative framework for IFRS in Russia Ministry of Finance in 2011 issued an order. According to the order 29 International Accounting Standards, 8 International Financial Reporting Standards and 26 Interpretations were enacted by this order. By issuing a special order the Ministry of Finance delegated the right of official publishing of International Financial Reporting Standards to Russian magazine «Accounting».

During the period under consideration substantial changes were made to the Federal law "On accounting" as well. The amendments to the Federal law had several consequences for Russian accounting system:

a) new four-level hierarchy of regulatory acts was approved (federal standards, industry-specific standards, recommendations in the field of the accounting, standards of economic entity);

b) the set of financial statements was revised and brought into the line with IFRS and thus starting from 2013 auditor's report was excluded from the set;

c) the obligatory use of standardized by the statistical authorities source accounting documents was cancelled in order to provide IFRS substance over form principle;

d) for small businesses simplified formats of balance sheet and income statements were developed;

e) several drafts of Russian Accounting standards were developed as well. These drafts included accounting standards concerning leases, revenue, employee benefits, inventories, property, plant and equipment.

Despite the development of infrastructure for IFRS Implementation it is still too far to fully adopt International Financial Reporting Standards into the Russian accounting system. A lot of issues such as the development of Russian Accounting Standards by professional organizations, the remaining differences between Russian Accounting Standards 
and International Financial Reporting Standards, the prevailing of juridical form over substance preserving in Russian Accounting system and some other problems still have to be solved.

\section{Results}

Existing accounting studies cover the issues of practical implementation of International Financial Reporting Standards mostly based on data for highly developed countries but not for developing countries. The intensifying processes of developing security markets, the need of funding for companies operating in countries with transitional economies such as Russia motivates management to provide high-quality information in financial reporting.

However in case with Russian companies it is not clear if the disclosure of information under International Financial Reporting Standards will help investors in getting high-quality information about financial position and financial results of companies. Historically the need for accounting under IFRS was higher for Anglo-American countries which are investororiented and have highly developed security markets [11]. Russian security market is too small in comparison with AngloAmerican countries as it is shown in Table 1.

Table 1: Security market capitalization based on World Federation of Exchanges data (\$ bln)

\begin{tabular}{|c|c|c|}
\hline Countries & Security market capitalization as of January 1, 2009 & Security market capitalization as of January 1,2013 \\
\hline Russia & 337,1 & 825,3 \\
\hline Anglo-American countries: & 11457,9 & 18668,3 \\
USA & 1868,2 & 3396,5 \\
Great Britain & 683,9 & 1386,9 \\
Australia &
\end{tabular}

Russian security market capitalization relatively to GDP of the country tends to decline as it is shown in Table 2 [14].

Table 2: Security market capitalization based on World Bank data (\% of GDP)

\begin{tabular}{|c|c|c|c|c|}
\hline Countries & 2008 & 2009 & 2010 & 2011 \\
\hline Russia & 23,9 & 70,5 & 67,5 & 42,9 \\
\hline Anglo-American countries: & & & & \\
USA & 82,5 & 108,5 & 118,9 & 104,3 \\
Great Britain & 69,6 & 128,1 & 137,3 & 118,7 \\
Australia & 64,2 & 136,5 & 127,7 & 86,9 \\
\hline
\end{tabular}

In the conditions of week security markets it is important to determine the extent of application of International Financial Reporting Standards by Russian companies. Mandatory IFRS-compliant financial statements will have to be submitted by Russian companies only for 2013. In the chosen time interval we examine the voluntary application of IFRS by listed companies. Our sample is made up of the companies listed on MICEX. Our initial sample for the period from 2005 to 2010 consists of 307 year-observations relating to a total of 71 companies.

In 2010 there were 265 companies listed on MICEX but most of these companies were parts of group of companies (For comparison: on London Stock Exchange there were listed 2767 companies, Australian Stock Exchange 2056 companies[12]). Russian companies listed on MICEX were not obliged to report consolidated financial statements under IFRS. For this reason we took only companies that actually reported under IFRS. We also eliminated 13 companies that report under US GAAP (Mechel, Cherkizovo Group, Gazpromneft, Gals Development, Mobile TeleSystems, MGTS, NLMK, Rosneft, Lukoil, Slavneft-Megionneftegaz, Sistema JSFC, Tatneft, TNK-BP (before take over by Rosneft) and firms with missing data.

Table 3: Selection of Sample Firms

\begin{tabular}{|l|c|c|c|c|c|c|c|}
\hline Year & 2005 & 2006 & 2007 & 2008 & 2009 & 2010 & Total \\
\hline Initial Sample & 106 & 106 & 106 & 106 & 106 & 106 & 636 \\
\hline Less: & & & & & & & \\
\hline Firms with missing data & 63 & 48 & 18 & 14 & 5 & 6 & 154 \\
\hline Firms with non-IFRS Statements & 13 & 13 & 13 & 13 & 13 & 13 & 78 \\
\hline Total & 30 & 45 & 75 & 79 & 88 & 87 & 404 \\
\hline
\end{tabular}


As it is shown in Table 3 starting from 2005 there was a steady growth of the number of Russian companies reported under IFRS. In critical 2007 the number of companies voluntary applying IFRS increased in 1.7 times from 45 to 75. Afterwards the growth was slowing down. In total the number of companies reported under IFRS increased in 2.9 times.

Table 4 gives an overview of application of accounting systems by Russian companies.

Table 4: Accounting systems applied by MICEX companies (\% of overall number of listed companies)

\begin{tabular}{|c|c|c|}
\hline Year & 2005 & 2010 \\
\hline Russian accounting standards & 83,8 & 62,3 \\
\hline IAS/IFRS & 11,3 & 32,8 \\
\hline US GAAP & 4,9 & 4,9 \\
\hline
\end{tabular}

The share of Russian companies voluntary applying IFRS increased since 2005 from $11,3 \%$ to $32,8 \%$. These results are consistent with European practice of IFRS adoption. To prove this we used data from German listed companies until the year 2000 when the EU announced its intention to make IFRS mandatory for all listed companies preparing consolidated financial statements (table 5).

Table 5: Accounting systems applied by German companies before 2000 (\% of overall number of listed companies)

\begin{tabular}{|c|c|c|c|c|}
\hline Year & 1997 & 1998 & 1999 & 2000 \\
\hline German GAAP & 70 & 47 & 27 & 17 \\
\hline IAS/IFRS & 20 & 37 & 53 & 53 \\
\hline US GAAP & 10 & 16 & 20 & 30 \\
\hline
\end{tabular}

The numbers demonstrate that German companies had favoured IFRS even prior to the EU announcement [11]. Before the mandatory adoption of IFRS half of the German companies (53\%) have already prepared financial statements in compliance with International Financial Reporting Standards. In Russia the share of such companies was lower - 32.8\%. In this respect one can expect the sharp rise of IFRS application by Russian companies in the future.

From 106 companies 16 of them chose US Dollar as a functional currency used for presentation of financial reporting under IFRS, 88 companies used rubles and 2 companies (Tattelekom and VTB Bank) had switches from one currency to another during the 2005-2010.

The other distinctive feature of Russian economy that influences the quality of financial reporting is a big share of lossmaking companies (table 6).

Table 6: Data on Russian companies reported profits and losses under IFRS

\begin{tabular}{|l|c|c|c|c|c|c|c|}
\hline Year & 2005 & 2006 & 2007 & 2008 & 2009 & 2010 & Total \\
\hline Initial Sample & 30 & 45 & 75 & 79 & 88 & 87 & 404 \\
\hline Less: & & & & & & & \\
\hline Firms reporting profits & 28 & 43 & 72 & 54 & 63 & 72 & 332 \\
\hline Share of companies reported profits, per cent & 93,3 & 95,6 & 96,0 & 68,4 & 71,6 & 82,8 & 82,2 \\
\hline Firms reporting losses & 2 & 2 & 3 & 25 & 25 & 15 & 72 \\
\hline Share of companies reported losses, per cent & 6,7 & 4,4 & 4,0 & 31,6 & 28,4 & 17,2 & 17,8 \\
\hline
\end{tabular}

Table 6 shows that during the period of 2005-2007 more than 93\% of Russian companies declared profits in consolidated financial statements under IFRS. In critical 2008 every third Russian company was loss making (31,6\%). Only in 2010 there was shown a positive sign of financial results improvement when the share of loss making companies decreased from c $31,6 \%$ to $17,2 \%$ (almost in 2 times).

45 from 106 Russian companies (42.5\% of overall number of companies) during the whole period of observation declared only profits in their financial statements. 9 companies ( $8.5 \%$ of overall number of companies) for the most period of 2005-2010 were loss making. These were such companies as United Aircraft Corporation, Transaero Airlines, Sollers OJSC, Rusgreyn Holding, RBK-TV Moscow, Quadra Power Generation, Pik Group, O2TV and Uralmash Izhora.

There was a small number of highly efficient Russian companies that showed only positive dynamics of net incomes in their financial statements under IFRS including Magnit, Gazprom, Novatek, Pharmstandard, Transkredibank, 
Transneft.

Table 7: Companies with highest net income growth rate

\begin{tabular}{|c|c|}
\hline Company & Net income growth rate 2010 to 2005, times \\
\hline Novatek & 2.95 \\
\hline Gazprom & 3.16 \\
\hline Pharmstandard & 3.52 \\
\hline Transkreditbank & 5.22 \\
\hline Magnit & 9.03 \\
\hline
\end{tabular}

The presentation of solid financial position and sound financial results in statements under IFRS might be helpful in the conditions of increasing demand to access capital markets. Regardless of legal requirements to prepare financial statements under IFRS many Russian companies have already implemented consolidated statements based on International Standards, driven by general economic conditions. Currently the challenge lies in enhancing acceptance of IFRS.

\section{Conclusions}

The article, investigating International Financial Reporting Standards into the Russian accounting system, implies that during developing the infrastructure for IFRS implementation by Russian Government in the long-drawn period of the last twenty years many companies driven the necessity of getting access to capital markets complied with IFRS on a voluntarily basis.

Although the system of statutory regulation has already underwent substantial changes there is a lot of issues that have to be solved in the future. The standards-setting process has be to changed towards delegating the functions of development of Russian Accounting Standards from statutory level to private sector bodies, the process of elimination of substantial differences between Russian Accounting Standards and International Financial Reporting Standards has to be continued in the future.

\section{References}

Albu, N., Albu, C.N. International Financial Reporting Standards in an Emerging Economy: Lessons from Romania // Australian Accounting Review 22 (4), 2013. pp. 341-352.

Alon, A. Complexity and Dual Institutionality: The Case of IFRS Adoption in Russia // Corporate Governance (Oxford) 21 (1), $2013 . \mathrm{pp}$. 42-57.

Christensen, H.B., Hail, L., Leuz, C. Mandatory IFRS reporting and changes in enforcement // Journal of Accounting and Economics 56 (2-3), 2013. pp. 147-177.

Fiori, G., di Donato, F., Macciocchi, D. IFRS and international differences: An empirical analysis on their application worldwide // Corporate Ownership and Control 11 (2 G), 20014. pp. 542-551.

Fox, A., Hannah, G., Helliar, C.,Veneziani, M. The costs and benefits of IFRS implementation in the UK and Italy // Journal of Applied Accounting Research 14 (1), 2013. pp. 86-101.

Hassan, E.A., Rankin, M., Lu, W. The Development of Accounting Regulation in Iraq and the IFRS Adoption Decision: An Institutional Perspective // The International Journal of Accounting (4 August), 2014. Article in press.

Paseková, M., Crhová, Z., Strouhal, J.,Řezanková, H. Positioning of Czech accountants towards IFRS implementation // WSEAS Transactions on Business and Economics 11 (1), 2014. pp. 283-292.

Pope, P.F., McLeay, S.J. The European IFRS experiment: Objectives, research challenges and some early evidence // Accounting and Business Research 41 (3), 2011. pp. 233-266.

Rózsa, I.B. Difficulties of applying IFRS in continental Europe from the perspective of codification // Periodica Polytechnica, Social and Management Sciences 21 (2), 2013. pp. 91-97.

Klichova G.S., Iskhakov A.T. The use of solar batteries in agriculture and accounting of generated electricity // Mediterranean Journal of Social Sciences.- Vol.5, No12, (2014)-pp.145 - 148.

United Nations Conference on Trade and Development, 2008. Practical Implementation of International Financial Reporting Standards: Lessons Learned. United Nations: New York and Geneva, 2008. Retrieved from: unctad.org/en/Docs/diaeed20081_en.pdf.

World bank, 2013. Market capitalization of listed companies. Retrieved from: http://data.worldbank.org/indicator/CM.MKT.LCAP.GD.ZS.

World Federation of Exchanges, 2013. Retrieved from: http://www.world-exchanges.org/member-exchanges. 